This article was downloaded by: [Australian National University]

On: 30 May 2012, At: 23:54

Publisher: Routledge

Informa Ltd Registered in England and Wales Registered Number: 1072954 Registered office:

Mortimer House, 37-41 Mortimer Street, London W1T 3J H, UK

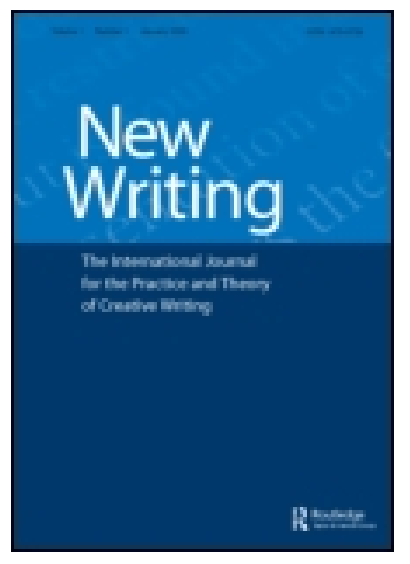

New Writing: The International J ournal for
the Practice and Theory of Creative Writing

Publication details, including instructions for authors and subscription information:

http:// www.tandfonline.com/loi/rmnw20

\title{
Unrealised Possibilities: Graduate Creative Writing Programmes in the USA
}

\author{
Lucy Neave ${ }^{a}$ \\ ${ }^{a}$ School of Humanities, Faculty of Arts, The Australian National University, \\ Canberra, ACT, Australia
}

Available online: $05 \mathrm{~J}$ an 2009

To cite this article: Lucy Neave (2006): Unrealised Possibilities: Graduate Creative Writing Programmes in the USA, New Writing: The International J ournal for the Practice and Theory of Creative Writing, 3:1, 56-64

To link to this article: http://dx.doi.org/ 10.2167/ new235.0

\section{PLEASE SCROLL DOWN FOR ARTICLE}

Full terms and conditions of use: http://www.tandfonline.com/page/terms-and-conditions

This article may be used for research, teaching, and private study purposes. Any substantial or systematic reproduction, redistribution, reselling, loan, sub-licensing, systematic supply, or distribution in any form to anyone is expressly forbidden.

The publisher does not give any warranty express or implied or make any representation that the contents will be complete or accurate or up to date. The accuracy of any instructions, formulae, and drug doses should be independently verified with primary sources. The publisher shall not be liable for any loss, actions, claims, proceedings, demand, or costs or damages whatsoever or howsoever caused arising directly or indirectly in connection with or arising out of the use of this material. 


\title{
Unrealised Possibilities: Graduate Creative Writing Programmes in the USA
}

\author{
Lucy Neave \\ School of Humanities, Faculty of Arts, The Australian National University, \\ Canberra, ACT, Australia
}

This paper examines the relationship between theory and praxis in the American Masters of Fine Arts programme. It reviews how creative writing is taught in the American graduate context, and investigates the fracture between the study of literature carried out in English courses and the discipline of creative writing, a break that has long been discussed in literature about writing pedagogy. In addition, it will discuss literary scholarship relevant to the teaching of creative writing, and make comments about the kinds of theoretical endeavours that may be useful to the graduate student writer.

doi: $10.2167 /$ new235.0

Keywords: MFA, publishing, writing workshop

I studied for a Masters of Fine Arts (MFA) in writing from 2000 to 2002 on the East Coast of the USA, and during that period felt fortunate to have so much time to concentrate on writing fiction and gain an understanding of how the publishing industry in New York operates. At the same time, though, other students and I sometimes wondered aloud about the fact that we did not feel intellectually challenged by the programme; that while we discussed literature in class we talked about books in terms of their formal qualities, a conversation in which we had been engaged since our undergraduate years. All the while, it felt as if something were missing, and when students talked about what this was, although I don't recall anyone invoking theory, students repeatedly mentioned that they would have liked a clearer sense of critical and artistic movements in literature, perhaps a broad course on literary history, and that this knowledge might help them to make sense of their own prose or poetry and its position in relation to the work of other, more established, writers. Perhaps these comments on the part of students were isolated; the product of the usual dissatisfactions that arise among students in graduate writing programmes. Since I returned to Australia, though, and realised that Australian writing programmes appear to be more engaged with academic literary scholarship, it prompted me to think about the strengths and weaknesses of the American graduate system.

In the USA most students who study writing at a graduate level study a Masters of Fine Arts in Writing (MFA), rather than a PhD. An MFA is a twoyear degree, which is composed of coursework (a workshop per semester and a series of craft courses) and a thesis. Students in MFA programmes may concentrate on fiction, poetry, playwriting, scriptwriting or creative nonfiction; 
a few universities offer degrees in new media writing as well, such as Brown University. This paper will discuss fiction and poetry MFAs, as students are most numerous in those programmes. Columbia University, New York University and the Iowa Writer's Workshop ${ }^{1}$ exemplify the traditional MFA in writing programme, but writing programmes offered in the USA assert diverse philosophical and theoretical positions.

The cornerstone of the graduate writing programme in the USA, as in England and Australia, is the workshop, in which a student's work is discussed by the instructor and other students, and suggestions are made for improvement. In the workshop, the formal qualities of a story or poem are examined and critiqued. Questions such as: 'how does point of view operate in this story?' and 'are the characters sufficiently well-developed?' are discussed. The writer of the piece is generally excluded from the conversation, instead listening to comments and suggestions from other students and the instructor. Towards the end of class the writer may ask questions or discuss his or her intentions for the poem or story.

In general the focus of discussion is on the work's formal qualities rather than its context. The pedagogical structure of the workshop is distinctive, and to some extent radical in that authority is decentralised; all members of the workshop can comment on a student's work, and the freeform discussions that take place in the workshop mean that students teach and learn from each other as much as from the instructor (Green, 2001). Workshops also emphasise reading, as students read and comment on each other's work, the idea being that through reading and critiquing another student's work, much can be learned about writing.

In craft classes, which students usually take in addition to a workshop for two semesters, there is also an emphasis on examining a work's formal qualities. Depending on the focus of the course, students discuss fiction or poetry by one writer or a number of writers in a seminar format. The aim of these conversations is to interrogate how literary works are assembled in order that they be demystified and understood by the developing writer (Myers, 1993). It is evident through statements by highly ranked Masters programmes, ${ }^{2}$ for example the MFA degree at Columbia, that there is little emphasis on engagement with literary studies. ${ }^{3}$ Close reading of texts in craft classes, as in the workshop, grew out of the New Criticism movement, at which time many of the most famous US graduate programmes came into being (Green, 2001; Myers, 1993). Such classes also encourage students to develop a certain aesthetic, and through this means, to gain a better understanding of what is publishable.

The MFA thesis is generally a creative thesis only; there is no imperative to include a theoretical exegesis or introduction. Students usually work on their thesis intensively during the second and final year of their MFA with the help of a thesis advisor, but it is also discussed in workshops. The emphasis is on revising the thesis in order that it approaches the quality of a published work, although the definition of publishable is somewhat ill defined by graduate programmes in the USA and elsewhere.

Instead of privileging links with academics engaged in the study of literature, then, graduate writing programmes are oriented towards the 
publishing industry. The links between the publishing industry and MFA programmes in the USA are close. Most programmes maintain these connections through: (1) bringing agents, publishers and/or established writers to speak to students; (2) staging student readings in front of agents / publishers; (3) supporting internships with publishing houses, literary magazines and journals; and perhaps most importantly (4) through connections between established writers and students, supporting a patronage system whereby thesis advisors recommend students to their agents. Therefore, emerging writers are encouraged to complete an MFA in order to be published. Agents and publishers tend to be supportive of graduate writing programmes, and to appreciate the links they have with individuals at various institutions because it provides them with potential authors. In many ways, this benefits students and the publishing industry.

There are definite strengths in the American system. Because creative writing as a discipline has been in existence for a long time, there is a large and growing literature about teaching and learning to write. Praxis and the building of networks between emerging and established writers are prioritised and encouraged. Connections with the publishing industry ensure that students are well informed about the process of publishing, and many writing programmes have an enviable calendar of readings by internationally renowned writers, with whom students can often have frank discussions.

Not only are ties with the publishing industry prioritised, but there is a suspicion of scholarship carried out in English departments in some of the creative writing literature. It is assumed that there is an opposition between literary scholarship, the academic study of fiction and poetry, and creative writing, in which students create texts. Fenza (2000: 58), executive director of the Associated Writing Programmes (AWP), in his paper 'Creative Writing and its Discontents', states that 'the application of literary theory often demotes writers - not for what they willed their works to say, but for what they did not will their works to say'. George Garrett (1992: 671), author of a paper entitled 'Creative Writing and Publishing Now', argues that in the late 20th century, 'literary criticism became, on the one hand, so abstract and theoretical as to be divorced from and irrelevant to the experience and needs of writers; or, on the other, so rigidly ideological as to inhibit imagination from anything but reflexive, outmoded, and stereotypical gestures'.

Is the privileging of ties with industry in any way problematic? A number of successful and innovative writers have graduated from US MFA programmes. On the AWP website Fenza (2001) lists Richard Ford, Joyce Carol Oates, Raymond Carver and many others. The degree is a professional one; ties between industry and the graduate writing programme are therefore necessary and desirable.

Despite the success of graduates, since the 1980s there have been numerous critiques of the graduate writing programme by the popular press and academics from English. Fenza (2000), in his defence of the creative writing programme, lists articles and books that have criticised the creative writing programme in the 1980s and 1990s including Gioia's 'Can Poetry Matter?', Aldridge's 'The New American Assembly-line Fiction' and Radavich's 'Creative Writing in the Academy'. 
But while Fenza defends the American graduate programme against charges that writing programmes are insular and have a defined and rigid aesthetic, there remain a number of voices from within the discipline of creative writing in the USA that have called for change. Recent papers by writers involved in the teaching of creative writing have argued that the fracture between praxis and the academic study of English is problematic. The reasons cited for this problem vary, but it is argued that the split between creative writing pedagogy and academic literary scholarship is deleterious because creative writing privileges a particular aesthetic; its focus on formal critique is rooted in New Criticism and modernism and is therefore 'backward'; and the exclusion of more recent literary scholarship from creative writing programmes is problematic (Berry, 1994; Green, 2001; Haake, 1994). Many criticisms of theories expounded by MFA programmes centre on the fact that creative writing programmes have borrowed from the discipline of English, but have retained an outmoded form of literary scholarship. Some writers are concerned that there is a lack of awareness on the part of instructors about how formalist critique is used by the workshop, and how the workshop operates (Domina, 1994; Green, 2001).

Among these critics, Berry (1994: 63), in 'Theory, Creative Writing and the Impertinence of History' suggests that: 'Creative Writing's differentiation of itself from literary study appears - to imitative poetics - as the severing of practice from its ground in the real life of language, the history of saying. The distinctive pedagogical innovation of Creative Writing - viz., the workshop - is a forum oriented exclusively to the present'. Berry argues that the workshop's privileging of imagination and individual experience is at the expense of a notion of history, and contrasts the manner in which people learned to write in the past, by imitation of other voices and by dialogue with writers who had gone before them, with the contemporary workshop where writers address their work to a literary marketplace comprised of average readers.

Berry (1994) sees the problem with creative writing pedagogy in the USA as a larger one; he believes it has political and social implications. Attempts by creative writing to enter the academy, through 'claiming universal grounds for its practice, e.g. artistic form, the constants of taste, the principles of good writing, poetic technique, humanist values etc' (Berry, 1994: 62-63) were deleterious to the discipline and also to literary studies, as they denied diversity. He sees creative writing as having diverged from literature programmes, as the writing programme claims universalist theories of literature, while English graduate degrees subscribe to historical ones ( $p$. 72). The professionalisation of creative writing, according to Berry (1994: 67), meant that the discipline, while divorced from currents in literary criticism, worked to solidify its position as a vocational degree, like Law and Medicine. As a result of this, Berry argues that creative writing, by allying itself with industry and the marketplace, has become too narrow and professionally oriented to be able to challenge the publishing industry's narrow aesthetic. Berry believes that creative writing, which as a discipline had the potential to critique the narrow view of what constitutes 'good' literature, has, through its alliance with the publishing industry, lost its ability to argue for inclusiveness and change. 
In many respects this is a powerful argument. However, several questions arise from Berry's paper, which he cannot address at any length as he is more interested in formulating the problem. The first idea raised by Berry's paper and others (Aldridge, 1990; Domina, 1994), is that creative writing programmes stifle the development of experimental writing, or writing from marginalised communities. But although courses in some writing programmes may appear guilty of this, graduates of creative writing programmes continue to produce interesting work. A number of MFA graduates have gone on to publish formally innovative prose and poetry. Works such as Charles Baxter's First Light and Lorrie Moore's short story collections, Self Help and Birds of America are examples of this (Passaro, 1999). It is difficult to argue that graduate writing programmes have stifled experimental writing, if the voices that have emerged from graduate writing programmes in the USA are examined closely. The question of whether creative writing programmes have been a force for change in the publishing industry is a different one altogether, as mainstream publishers maintain, and will in all likelihood continue to argue, that only certain kinds of fiction are marketable, and therefore neglect those thought to be unfashionable. As Berry suggests, more could be done by MFA programmes to support innovative and critically engaged writing, and through this means, to critique the sometimes conservative choices made by publishers.

A number of questions arise, then, from discussions about MFA pedagogy that have some relevance for writing programmes in the USA and other countries. In many respects, the MFA degree is successful in producing a number of interesting writers, or supporting the development of writers who may have gone on to be interesting with or without an MFA degree. But the question remains: what kind of theoretical education is appropriate for developing writers? Postcolonial theory, Cultural Studies and Narrative Theory have been discussed (Freiman, 2001; Green, 2001; Haake, 1994) and the relative merits of these theories and others (Dawson, 1997) have been argued over in Australian and American journals and no conclusions have been reached. Do writers need theory at all? Several successful contemporary writers have not had an undergraduate education, let alone a course on narrative theory, for example. Why is it important to discuss and formulate a relevant 'reading' theory for creative writers, when it's obvious that theories of production for creative works are entirely distinct from theories of interpretation?

In all likelihood, this issue will continue to be discussed in literature about creative writing pedagogy simply because writers learn from reading. How writers learn from other writers' fiction and poetry, and use what they learn, has been mapped incompletely; anecdotally. But it seems that teaching close textual analysis alone is not enough. Instead, it may prove useful to provide writers with a broad history of criticism; to give student writers a series of lenses through which to view their own and others' work. How these critical frameworks or ways of reading could be chosen or constructed is another area of debate, but it seems important to give students a variety of ways of approaching published texts, as well as works by fellow students. LaFemina (2004: 1) writes: 'As a practicing poet, it's my critical work - whether I publish it or not - that clarifies and propels my creative endeavors (the scope of my 
vision, as it were) and what I learn from crossing fences allows me to move forward as a writer and teacher.' Reading literary scholarship, and writing about others' work in a variety of critical ways may provoke further thought about students' intentions as writers, or about where their work is situated with reference to the works of others or about how language is used. A more extensive literary education of MFA students would be useful, not simply because it might feed graduates' own writing, but because it might help them to teach - many MFA graduates in fact go on to teach composition and undergraduate creative writing classes.

There have been discussions about the current configuration of the MFA in both popular and academic literature since the 1980s, but criticism of the graduate writing programme and workshop have been largely ignored by the traditional programmes on the East Coast of the USA and the Iowa Writer's Workshop. In some quarters, though, some changes and developments have occurred in the conceptualisation of the workshop, although many of these developments have occurred in undergraduate education and have yet to be employed or modified for use in the graduate context.

Chris Green (2001), who primarily works with undergraduates, is the author of 'Materializing the Sublime Reader: Cultural Studies, Reader Response and Community Service in the Creative Writing Workshop', in which he critiques the way traditional workshops are run, stating that the promise implicitly made in the creative writing workshop, that of discovering voice, of discovering oneself and developing as a writer, is often thwarted by how the workshop operates. Green (2001) views the writing workshop in the USA as being dominated by 'The Sublime Reader', an unacknowledged presence in the workshop which is manifest through pedagogical instruction that teaches students how to write well. Like Berry, Green argues that students are taught to address their work to the market. ${ }^{4}$ As a result, according to Green (2001: 3), 'the workshop feigns a presence of the sublime reader from this market for the adequate preparation of its students'.

Green (2001) critiques the idea of the good in the workshop, arguing that the goal of writing well entails much unspoken ideological baggage, including objective standards of 'good' and humanist assumptions about value and worth. Instead, Green argues that writing be valued, not for its success as a commodity, but for its ability to have a use for particular communities. Green's point that the concept of the sublime reader dictates student and teacher response to student work is valid, and suggests that the idea of the good in workshop be further critiqued. Green also suggests that writing from and for particular communities helps break down universalist assumptions about good writing.

Green (2001) goes on to make some suggestions for how cultural studies and exploration of the writing from different communities be brought into the workshop. He stresses the need for discussing texts in a broader way than that dictated by new criticism, and argues that texts be discussed in the context in which they are written. He gives examples of exercises he gives to his students: he asks students to think about how their poems fit into or change a tradition of poems and by this means explore their relationship with the canon. 'One way to widen the list of rhetorical purposes and techniques might 
be to have students compile a list of terms that they feel are appropriate to evaluating their poetry...What becomes obvious from an examination of these defenses is the historical contingency of the use of poetry in terms of power and authority around religion, nationality, class and gender' (Green, 2001: 5).

Paul Kane, a professor of English at Vassar College, teaches an undergraduate senior seminar in composition, and has the luxury of working with his students for a full year during which time students pass through different stages in revising and rethinking their work. In the first month or so of the class, Kane's students read a book a week, discuss it in class, with close attention to the writing and structure, and build a critical context and vocabulary. Kane then encourages students to read student texts through a series of conceptual and theoretical frames, beginning with a more traditional workshop format and ending with what he terms a 'phenomenological approach' where the work is no longer considered a work in progress but a finished one.

Kane's suggestion, of reading the same student texts in a series of different ways, seems a useful one, and could be employed in graduate writing workshops; or, different ways of reading could be used in successive workshops (Kane, 2004).

A further modification of the MFA may be to include courses that study literature not simply from a formalist position, but from a number of vantage points. This would give students a greater understanding of critical movements in literature and literary history, and a sense that notions of what constitutes 'good' literature are not fixed. While a broad and deep study of literature is probably impossible in a two-year degree, further engagement with contemporary and historical currents in literary scholarship may be helpful to the student. An obvious reform might be to require students to write a theoretical exegesis as part of their thesis, as in many Australian and English $\mathrm{PhD}$ and Masters programmes.

At the same time, though, more effort could be made on the part of academic scholars in English to recognise the contributions of creative writing to the understanding of literature; this would help mend the fracture between the disciplines of English and creative writing. In the undergraduate context, through writing fiction and poetry, students realise that texts are constructed through a lengthy and difficult process; that they do not emerge, fully formed, from the mind of a literary genius. While this may seem an obvious point, creative writing influences students' understanding of how texts are produced. Even for students who do not go on to work as writers, this understanding of how prose and poetry is made is invaluable for their understanding of literary texts, and is attained through the writing process.

In the USA, the MFA occupies a unique position in the academy. The programme, its students and the writers who teach them are in a position where they can negotiate between the academy and industry; they can critique the literary marketplace and work to broaden ideas about what is publishable and the communities to which published work can be addressed. Changes in how the workshop is run may benefit the student; it may also support those students working on experimental literary texts, or writing from outside the mainstream. Creative writing programmes may, in the end, position 
themselves more firmly where they are strongest - at the maddening and problematic nexus of theory and practice.

\section{Correspondence}

Any correspondence should be directed to Lucy Neave, School of Humanities, Faculty of Arts, The Australian National University, Canberra, ACT 0200, Australia (Lucy.neave@anu.edu.au).

\section{Notes}

1. The Iowa Writers' Workshop website states 'The Writers' Workshop has served as a blueprint for university-based creative writing programs, which have collectively transformed the terrain of American literary life.'http://www.uiowa.edu/ iww/index.html.

2. According to the US News and World Report Ranking System http://www. usnews.com/usnews/edu/college/rankings/brief/natudoc/tier1/t1natudoc_ brief.php.

3. This is apparent on the Columbia University graduate writing programme website: 'Our workshops, master classes, seminars and lectures are created for writers, by writers who discuss student work and literature from a practitioner's perspective, not that of a scholar or theorist.' http:/ /www.app.cc.columbia.edu/art/app/arts / writing/index.jsp

4. Green (2001: 54) also refers to Fenza's paper, 'Creative Writing and its Discontents', in which Fenza writes that students in creative writing programmes are taught to address their work to 'the public and the markets that serve the public'.

\section{References}

Aldridge, J.W. (1990) The new American assembly-line fiction. The American Scholar 59 (1), 17-38.

Berry, R.M. (1994) Theory, creative writing, and the impertinence of history. In W. Bishop and H. Ostrom (eds) Colors of a Different Horse: Rethinking Creative Writing Theory and Pedagogy (pp. 57-76). Urbana, IL: National Council of Teachers of English.

California Institute of the Arts (2004) California Institute of the Arts MFA in Writing. California Institute of the Arts. On WWW at http://www.calarts.edu/ writing/, 14 May.

Dawson, P. (1997) The function of critical theory in tertiary creative writing programmes. Southern Review: Literary and Interdisciplinary Essays 30, 70-80.

Domina, L. (1994) The body of my work is not just a metaphor. In W. Bishop and H. Ostrom (eds) Colors of a Different Horse: Rethinking Creative Writing Theory and Pedagogy (pp. 27-35). Urbana, IL: National Council of Teachers of English.

Fenza, D.W. (2001) Brief history of the AWP. Associated Writing Programs. On WWW at http://awpwriter.org/aboutawp/index.htm. Accessed 2.11.03.

Fenza, D.W. (2000) Creative writing and its discontents. Writers Chronicle 22, 50-60.

Freiman, M. (2001) Crossing the boundaries of the discipline: A post-colonial approach to teaching creative writing in the university. Text 5 (2), 1-15. On WWW at http:/ / www.gu.edu.au/school/art/text/. Accessed 5.5.04.

Garrett, G. (1992) Creative writing and American publishing now. Sewanee Review 100, $569-575$.

Green, C. (2001) Materializing the sublime reader: Cultural studies, reader response and community service in the creative writing workshop. College English 64, 1-10. On WWW at http:/ / proquest.umi.com. Accessed 12.11.03.

Haake, K. (1994) Teaching creative writing if the shoe fits. In W. Bishop and H. Ostrom (eds) Colors of a Different Horse: Rethinking Creative Writing Theory and Pedagogy (pp. 77-100). Urbana, IL: National Council of Teachers of English.

Kane, P. (2004) 'Re: Questions.' Email to the author. 5 May. 
LaFemina, G. (2004) Lab work: Creative writing, critical writing, creative obsessions and the critical essay. Text 8 (1), 1-2. On WWW at http://www.gu.edu.au/school/ art/text/. Accessed 14.5.04.

Myers, D.G. (1993) The rise of creative writing. Journal of the History of Ideas 54, 277-297.

Passaro, R. (1999) Unlikely stories: The quiet renaissance of American short fiction. Harper's Magazine Aug., 80-90.

Ramey, L. (2001) Creative writing and English studies: Two approaches to literature. Position Paper on WWW at http://english.heacademy.ac.uk/archive/events/ cwriting/Ramey.rtf. Accessed 27.10.03. 